\title{
A 11-18 ÉVES FIATALOK ORSZÁGOS, REPREZENTATÍV TÁPLÁLKOZÁSI ÉS FIZIKAI AKTIVITÁSI VIZSGÁLATA
}

\section{REPRESENTATIVE NUTRITIONAL AND PHYSICAL ACTIVITY STUDY IN HUNGARY AMONG 11-18 YEARS OLD CHILDREN}

\author{
Antal Emese', Pilling Róbert ${ }^{2}$, Kốris Tamás ${ }^{3}$, Bíró Lajos ${ }^{4,5}$ \\ ${ }^{1}$ MSc, regisztrált dietetikus, TÉT Platform, Budapest \\ antal.emese@tetplatform.hu \\ ${ }^{2}$ regisztrált dietetikus, TÉT Platform, Budapest \\ pilling.robert@tetplatform.hu \\ ${ }^{3}$ MSc, okleveles közgazdász, InsightLab Kft., Budapest \\ tamas.koris@insightlab.hu \\ ${ }^{4} \mathrm{PhD}$, MD, Nutricomp Bt. \\ biro@@nutricomp.hu \\ ${ }_{5}^{5}$ Semmelweis Egyetem Egészségtudományi Kar Dietetika és Táplálkozástudományi Tanszék, Budapest
}

\section{ÖSSZEFOGLALÁS}

Bevezetés: A gyerekek életmódja és azzal kapcsolatos attitűdje, tudásszintje jelentős hatással van a későbbi életkorokban kialakuló, életmóddal összefüggő krónikus megbetegedések megelőzésére.

Cél: A felmérés célja a 11-18 éves fiatalok életmódjának megismerése, különös tekintettel a táplálkozási szokásokra, ismeretekre és a tápanyagbevitelre. További cél az egészséges életmódra vonatkozó ismeretek és attitüdök feltárása, valamint a fizikai aktivitás felmérése.

Anyag és módszer: A TÉT Platform által kezdeményezett vizsgálat keretében 2016-ban és 2017-ben Budapesten, valamint négy régió nagyvárosaiban és azok vonzáskörzeteiben élő 11-18 éves fiatalok $(n=800)$ felmérésére került sor. Antropometriai vizsgálat, "háromnapos" táplálkozási napló felvétele, valamint az életmóddal kapcsolatos attitűd, tudásszintfelmérő kérdőív lekérdezése történt.

Eredmények: A vizsgált népesség 70\%-a egészségesnek gondolja a saját életmódját, és csak nagyon kevesen (3\%) tartják azt inkább egészségtelennek. A fiatalok szerint a még egészségesebb életmód leginkább több sporttal és nagyobb kitartással lenne elérhető. A fiatalok BMI-kategóriák szerinti megoszlása: 7,3\% sovány; 69,1\% normál, 18,4\% túlsúlyos, 5,1\% elhízott volt. A napi energiabevitel átlaga a 11-14 évesek és mindkét nem esetében megfelelt az ajánlásnak (2703 és $2392 \mathrm{kcal})$. A 15-18 évesek esetében többlet energiabevitel legmagasabb arányban (21,8\%) a 17-18 éves fiúk esetében volt megfigyelhető. A zsírokból származó energia\% (en\%) minden korcsoport és mindkét nem esetében 5-6\%-kal az ajánlott maximum (30 en\%) felett volt. Az n-3 és n-6 zsírsavak aránya átlagosan 1:27 volt (az ajánlott 1:5 helyett). A szénhidrátból származó energia átlaga jóval alatta (49\%) volt az ajánlott 57 en\%-nak, de ezen belül a hozzáadott cukorból származó energia meghaladta (11,7 en\%) az ajánlott 8, maximum 10 en\%-ot. Az ásványi anyagok közül a nátrium és a foszfor esetében jelentős többletbevitel volt jellemző, míg nagyobb fokú (22-34\%) hiányos bevitel a kalcium, vas (elsősorban lányok), kálium és a cink 
esetében volt tapasztalható. A vitaminok esetében a D-vitamin igen jelentős (98\%), a retinol ekvivalens és a folsav esetében is nagyarányú (43-55\%) hiányos bevitellel kell számolni. Az élelmiszer-fogyasztásban a zöldség- és gyümölcsfélék együttes mennyisége jóval alatta volt az adott korcsoportú fiatalok számára ajánlott (kb. $400-450$ g) mennyiségnek. A teljes értékű gabonák és (barna) kenyérfélék napi fogyasztott mennyisége alacsony volt. A tej- és tejtermékek összesített fogyasztása 309 g/nap volt, elmaradt a kívánatos mintegy 500 g/nap mennyiségtől.

Következtetés: A 11-18 éves fiatalok életmódjában, egyes élelmiszercsoportok fogyasztásában, attitűdjében, tudásában már felfedezhetők a felnőtt lakosságra is jellemző hibák nyomai.

\section{ABSTRACT}

Introduction: The lifestyle, attitudes and knowledge levels of children have a significant impact on the prevention of lifestyle-related non-communicable diseases in later stages of life.

Objective: The aim of this survey was to familiarize the lifestyle of young people between the ages of $11-18$, with special regard to their eating habits, knowledge and daily intakes. Other objectives were to find out attitudes, knowledge of the healthy lifestyle, and assess physical activity.

Material and Method: As an initiative by TÉT Platform, the study used $n=800,11-18$ years old participants living in four regions of Hungary (the capital, large and small cities and their suburbs) in the end of 2016. Anthropometric measures, 'three-day' dietary diary, and a lifestyle-related attitudes-knowledge-level questionnaire was used in the survey.

Results: $70 \%$ of the examined population consider their own lifestyle healthy and only very few $(3 \%)$ acknowledge it unhealthy. They think the healthier way of life would be more achievable through more sports and more persistence. Distribution of young people by BMI categories: $7.3 \%$ thin, $69.1 \%$ normal, 18.4 overweighed, $5.1 \%$ obese. The average of the daily energy consumption met the recommendation in both sexes and in the group of 11-14 years old young people (2103 and $2392 \mathrm{kcal}$ ). Excess energy intake was observed in the group of the 17-18 years old boy participants (21.8\%). Energy intake from fat (en\%) was 5-6\% higher than the recommended maximum (30 en\%) in both sexes and all age groups. The ratio of $n-3$ and $n-6$ fatty acids was 1:27 in average, more than the recommended 1:5 ratio. Energy intake from carbohydrates was lower (49 en\%) than the recommendation (57 en\%), but the energy intake from added sugar was higher (11.7 en\%) than the recommended 8, maximum 10 en\%.

From the minerals, significant excess intake was observed in the case of sodium and phosphorus, while inadequate intake of calcium, iron (mainly girls), potassium and zinc was found to be higher (22-34\%). For vitamins, inadequate intake of the D-vitamin is the most common (98\%), but the lower intake is very significant in the case of retinol-equivalent and folic acid (43-55\%).

In terms of food consumption, the total amount of vegetables and fruit was fairly below the recommended amount (about 400-450 g/day) in all age group and both sexes. The consumption of whole grain cereals and (brown) bread were low. Total consumption of milk and dairy products was $309 \mathrm{~g} /$ day, which is significantly less than the recommended $500 \mathrm{~g} /$ day.

Conclusion: In the lifestyle of young people between the ages of 11 and 18, traces of mistakes those are typical of the Hungarian adult population's attitudes, knowledge and in the consumption of certain food groups, can already be discovered.

Kulcsszavak: ifjúság, táplálkozási napló, egészséges életmód, oktatás, tápanyagbevitel

Keywords: young, dietary diary, healthy lifestyle, education, nutrient intake 


\section{BEVEZETÉS}

A gyermekek és serdülők optimális növekedéséhez, testi, lelki, értelmi fejlődéséhez elengedhetetlen az egészséges táplálkozás és a rendszeres fizikai aktivitás. Aktuális egészségi állapotukhoz is jelentősen hozzájárul a kiegyensúlyozott, változatos táplálkozás, és szerepe lehet a hosszú távon jelentkező egészségi problémák kivédésében is (CDC, 1997).

Fiatal korban a viszonylag rövid idő alatt lezajló erőteljes testi és szellemi fejlődéshez nagy energia és számos fontos tápanyag többletbevitele szükséges. A táplálkozási szokások kialakulása gyermekkorban zajlik, amelynek bizonyítottan egészségmegőrző, betegségmegelöző szerepe van. A fiatal korban fogyasztott ételek minősége, mennyisége és gyakorisága hatással van a testösszetételre, a fizikai és kognitív állapotra még felnőttkorban is.

Fiatal korban az étkezési szokásokat és ételválasztást számos és a korábbiaknál több tényezö befolyásolja: az önállósodás, a társas kapcsolatok, az otthonon kívüli gyakoribb étkezés stb. (Story et al., 2002). Ha ebben a korban nem megfelelő a táplálkozás, az a fenti szempontokkal együtt hozzájárulhat egészségtelen táplálkozási szokások kialakulásához.

Az étkezési szokások egyik fontos eleme a főétkezések gyakorisága, rendszeressége. Ezek közül a táplálkozástudomány álláspontja alapján - föleg az iskolába járó fiatalok számára - a legfontosabb a reggeli. Számos tanulmány megállapította, hogy iskoláskorban a rendszeres reggelizés jobb tápanyag-ellátottságot biztosít, és akár a túlsúlyossággal is fordított összefüggést mutat (Pedersen et al., 2012).

Nemzetközi viszonylatban és hazánkban is a HBSC (Health Behaviour in School-Aged Children) kutatás az egyik fontos forrásunk az iskoláskorú gyermekek egészség-magatartásával kapcsolatosan. A több mint harminc éve elindult nemzetközi adatfelvétel negyvennél több országban zajlik egységes módszertannal, négyévenkénti gyakorisággal. A vizsgálat átfogóan méri fel az iskoláskorú gyermekek egészség-magatartását, beleértve többek között a táplálkozást, a testképpel kapcsolatos jellemzőket, a fizikai aktivitást.

A legutóbbi magyarországi HBSC-kutatás alapján kiderült, hogy a fiatalok egészségmagatartása nem mondható optimálisnak. A kívánatosnál rosszabb helyzetet jelez, és európai viszonylatban is átlagos vagy annál kedvezőtlenebb képet mutat a magyar serdülőkről (Németh-Költő, 2014).

A gyerekek életmódja és azzal kapcsolatos attitüdje, tudásszintje jelentős hatással van a későbbi életkorokban kialakuló, életmóddal összefüggő krónikus megbetegedések megelőzése szempontjából. Ezért is fontosak azok az irányelvek, amelyek meghatározzák az egészséges táplálkozás főbb pontjait. A WHO 2017-ben kiadott egy ilyen útmutatót a fiataloknak, amely meghatározza többek között a legfontosabb ajánlásokat a táplálkozás, illetve fizikai aktivitás terén (WHO, 2017). 
A gyermekkori elhízás komoly népegészségügyi problémát jelent napjainkban (Lobstein et al., 2015). Az elhízás nem csupán esztétikai gondot okoz, hanem már gyermekkorban számos betegség előfordulásának kockázatát növeli (például: magas vérnyomás, cukorbetegség, depresszió). Mindennek ellenére a gyermekkori elhízás előfordulási gyakorisága nő. Egy friss vizsgálat 6-8 éves gyermekek körében vizsgálja a túlsúly és az elhízás előfordulását az egyes régiókban. A túlsúly prevalenciája $12 \%$, míg az elhízásé $6,2 \%$ tartományon belül változik hét régióban. A regionális különbségek jelentősek. Észak-Magyarországon és Dél-Dunántúlon volt a legmagasabb az elhízás előfordulása, míg Közép-Magyarországon volt a legalacsonyabb. A megfigyelt regionális különbségek magyarázata érdekében megvizsgáltak számos tényezőt, és összefüggést találtak a regionális GDP-adatokkal. A túlsúly és az elhízás legalacsonyabb előfordulását figyelték meg abban a régióban, ahol a GDP a legmagasabb, és a legmagasabb prevalenciát azon a területen, ahol a GDP a legalacsonyabb volt (Erdei et al., 2018).

Az anyagi kérdések tekintetében kutatások bizonyítják, hogy azon személyek, akik alacsonyabb iskolai végzettséggel és jövedelemmel rendelkeznek, kevésbé követnek egészséges étrendet, mivel náluk föleg az ár dominál, valamint kérdéses, hogy ismerik-e az adott terméket. Kevésbé fontos szempont a termék egészségessége (EUFIC, 2012).

A szegényebbek nem tudnak változatosságot teremteni étrendjükben, összehasonlítva a magasabb szociális státuszúakéval alacsonyabb a zöldség- és gyümölcsfogyasztásuk (Konttinen, 2013).

A több mint 16000 gyermek vizsgálatával zajló I. family kutatás megállapította, hogy azon gyermekek körében, akik szegényebbek, illetve bevándorlók, nagyobb a túlsúlyosak és elhízottak aránya, mint a gazdagabb rétegböl származóknál. Egészségtelenebbül táplálkoznak azok, akik szegényebbek, illetve szüleik alacsonyabb iskolai végzettséggel rendelkeznek (Ahrens et al., 2014).

Éppen ezért a WHO legújabb anyagaiban és cselekvési tervében külön felhívja a figyelmet az alacsonyabb, illetve magasabb szocioökonómiai státuszú felnőttek és gyermekek tápláltsági állapotában és étkezésében, életmódjában megfigyelhető különbségekre (WHO, 2014; WHO, 2016).

A fiatalok az egészségük, táplálkozásuk terén is egyre inkább a számítástechnika nyújtotta információkhoz fordulnak.

Irene A. Nikoloudakis és munkatársai 2016-os kutatása szerint az internetezők 65\%-a keres egészségügyi információkat a világhálón, és szinte hajszálpontosan ezt az adatot erösíti meg a Szinapszis Kft. 2016 decemberében, reprezentatív mintán végzett hazai kutatása az internetes egészségügyi információszerzésről (Nikoloudakis et al., 2016; Kis, 2016). Mindeközben az orvosokat és az egészségügyi szakembereket hiteles forrásként tartják számon, ami rámutat a digitális ismeretterjesztésben, egészségnevelésben rejlő, kihasználásra váró potenciálra (NEFI, 2015). 
Korábbi nemzetközi kutatások is rávilágítottak arra, hogy a megfelelő táplálkozással kapcsolatos egyik fö probléma a fiatalok alapismereteinek hiányából adódik. Általában nem ismerik az alapszabályokat (milyen testtömeghez, mekkora fizikai aktivitáshoz mennyi energia-/kalóriabevitel szükséges, vannak-e olyan élelmiszer-összetevők, amelyek különösen előnyösek stb.), és ezek alapján szürnék meg az egészségi állapotuknak és életmódjuknak megfelelő ajánlásokat, így szinte minden információt megpróbálnak - kritikátlanul - követni. De mivel nem képesek eligazodni az egészséges életmód körüli ,információcunamiban”, általánosításokkal próbálják egyszerüsíteni az eligazodást. Mindez óhatatlanul tévhitek kialakulásához, legtöbb esetben a számukra helyes életmód megtalálásáért folytatott küzdelem feladásához, a különböző tévhitek közötti vergődéshez és ad hoc döntésekhez vezet.

Bebizonyosodott, hogy a felnőttkori szokások, életmódbeli elemek és ezek következtében a hosszú távú egészség gyermekkorban alapozódik meg, ezért nagyon fontos lenne a serdülőkori kedvezőtlen egészségmagatartási tendenciákat megállítani, de legalább mérsékelni.

\section{A VIZSGÁLAT CÉLJA}

A felmérés célja a 11-18 éves fiatalok életmódjának megismerése, különös tekintettel a táplálkozási szokásokra, ismeretekre és a tápanyagbevitelre. További cél az egészséges életmódra és táplálkozásra vonatkozó ismeretek és attitüdök feltárása, valamint a fizikai aktivitás felmérése.

\section{ANYAG ÉS MÓDSZER}

\section{A beválasztás és a vizsgált csoportok}

A felmérés az Egészségügyi Tudományos Tanács Tudományos és Kutatásetikai Bizottság (ETT TUKEB) engedélyével történt. A vizsgálatvezető TÉT Platform megbízásával a vizsgálatot a Magyar Dietetikusok Országos Szövetsége (MDOSZ), az InsightLab Piackutató Kft., valamint a NutriComp Bt. végezte. A vizsgált személyek az életkor, nem és terület alapján rétegzett mintakiválasztás alapján kerültek beválogatásra, a következők szerint:

- 11-18 évesek, tervezetten bevonandók száma $\mathrm{N}=600$ fö;

- a vizsgálni kívánt életkori kohorszok: 11-12 évesek; 13-14 évesek; 15-16 évesek; $17-18$ évesek;

- a vizsgált területek: Budapest, illetve két-két kelet-, illetve nyugat-magyarországi város és környéke. 
Két vizsgálatot végeztünk el: kérdőíves felmérés keretében vizsgáltuk a fiatalok életmódra, egészséges táplálkozásra vonatkozó tudását, attitüdjét, illetve fizikai aktivitását, ezek keretében rákérdeztünk a leggyakoribb tévhitekre is, és háromnapos táplálkozási napló vizsgálattal felmértük a fiatalok tápanyagbeviteli szokásait.

1. A táplálkozási és fizikai aktivitásra vonatkozó kérdőívet 818 gyerek töltötte ki.

2. A háromnapos táplálkozási napló vizsgálatban összesen 803 11-18 éves fiatal táplálkozási kérdőíve került feldolgozásra.

1. táblázat. Korcsoportonkénti megoszlás

\begin{tabular}{|l|c|c|}
\hline & $\mathbf{n}$ & $\mathbf{\%}$ \\
\hline $11-12$ évesek & 205 & 25,5 \\
$13-14$ évesek & 199 & 24,8 \\
$15-16$ évesek & 208 & 25,9 \\
$17-18$ évesek & 191 & 23,8 \\
összesen & 803 & 100,0 \\
\hline
\end{tabular}

A táplálkozási kérdőívek verifikálását követően 644 fiatal kérdőíves adatai bizonyultak megbízhatónak (normál bevitel), 126 személy (15,7\%) alájelentő, 33 $(4,1 \%)$ föléjelentő volt; hiányos kiegészítő adatai miatt két személy kizárásra került. A későbbiekben már csak a megbízható (normál energiabevitelt jelentő személyek) adatok kerültek statisztikai elemzésre. $47 \%$ férfi, 53\%-uk nő volt.

\section{EREDMÉNYEK}

\section{A fiatalok tudását, attitüdjét, tévhiteit vizsgáló kérdöives vizsgálat eredményei}

\section{1a. Fizikai aktivitás vizsgálata}

Közel $80 \%$ legalább hetente egyszer, kétharmaduk heti többször is intenzíven mozog az iskolán kívül is. Minden nyolcadik gyereknél ez a hét minden napján megtörténik, de ugyanennyien vannak azok is, akik gyakorlatilag sosem mozognak aktívan. Ötből hárman heti rendszerességgel sportolnak, minden negyedik versenyszerüen; ezekben legnépszerübb a foci.

A fiatalok egyötödének nem tartozik a kedvelt szabadidős tevékenységei közé a tévézés, és ugyanennyinek a kütyüzés/videojátékozás sem, így összességében a hétköznapi átlag 1,5 óra, a hétvégi valamivel kevesebb mint 2 óra körül alakul mindkét tevékenységnél, enyhe eltolódással a kütyük javára (1. ábra). 


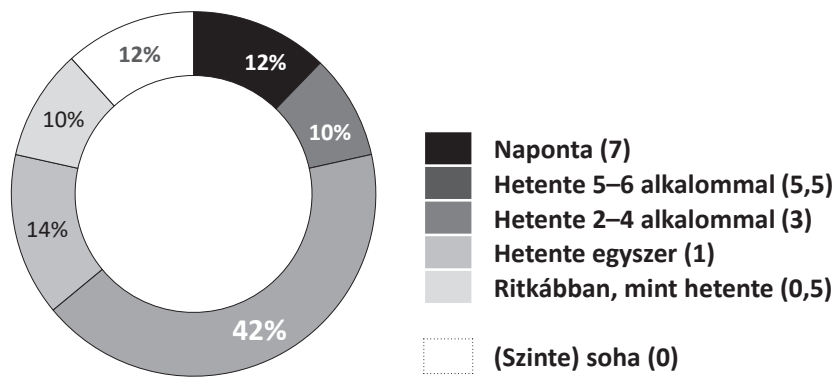

1. ábra. Mozgásmennyiség

A nagy többség elégedett az állóképességével: minden ötödik gyerek kifejezetten jónak, további több mint $40 \%$ jónak tartja az álló-/teherbíró képességét, és csak $3 \%$ nem elégedett vele. Az elégedetlenek aránya még a túlsúlyosak (beleértve a kórosan elhízottakat is) körében is relatív alacsony (8\%), alig több mint a budapestiek körében összességében (7\%). Kor szerint nincsenek lényeges különbségek, de a fiúk elégedettebbek, mint a lányok.

A gyerekek valamivel többet töltenek számítógépezéssel/mobilozással, mint tv/videók nézésével, de mindkettő átlaga napi 1,5-2 óra körül alakul. A hétvégén mindkettőre több időt szánnak: 20\%-kal többet a gépre/mobilozásra, 40\%-kal többet a tv-re. A tévénézéssel töltött idöben nincs különbség a nemek és korosztályok között, a „kütyük” népszerübbek a fiúk és az idősebb gyerekek körében. Hétvégenként a gyerekek fele, hét közben egyharmada tölt napi 2 óránál többet gépezéssel/ mobilozással; tv esetében ez az arány 40, illetve $20 \%$ körüli (2.,3. ábra).
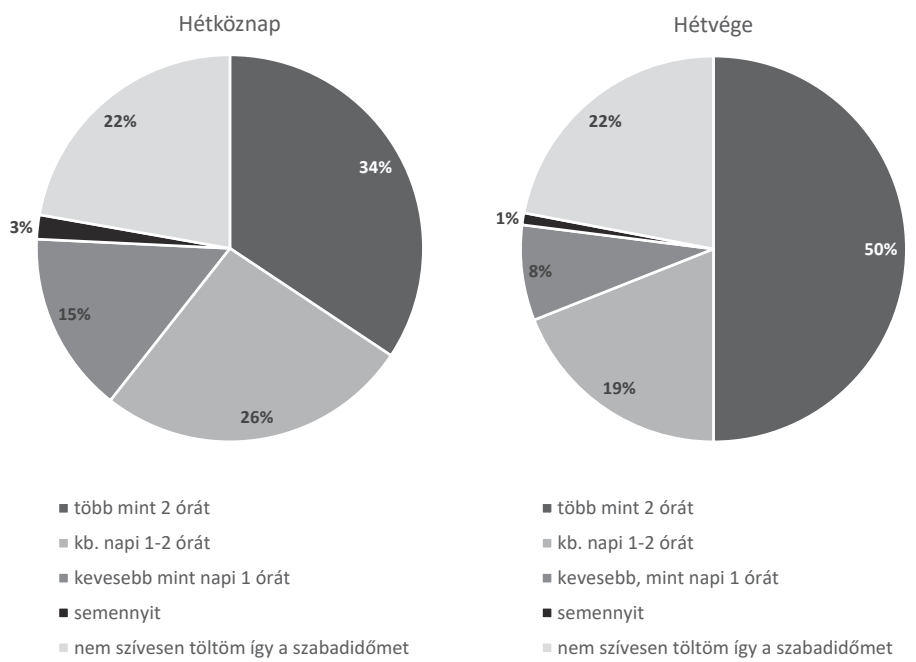

2. ábra. Számítógépezéssel töltött idő hétköznap 

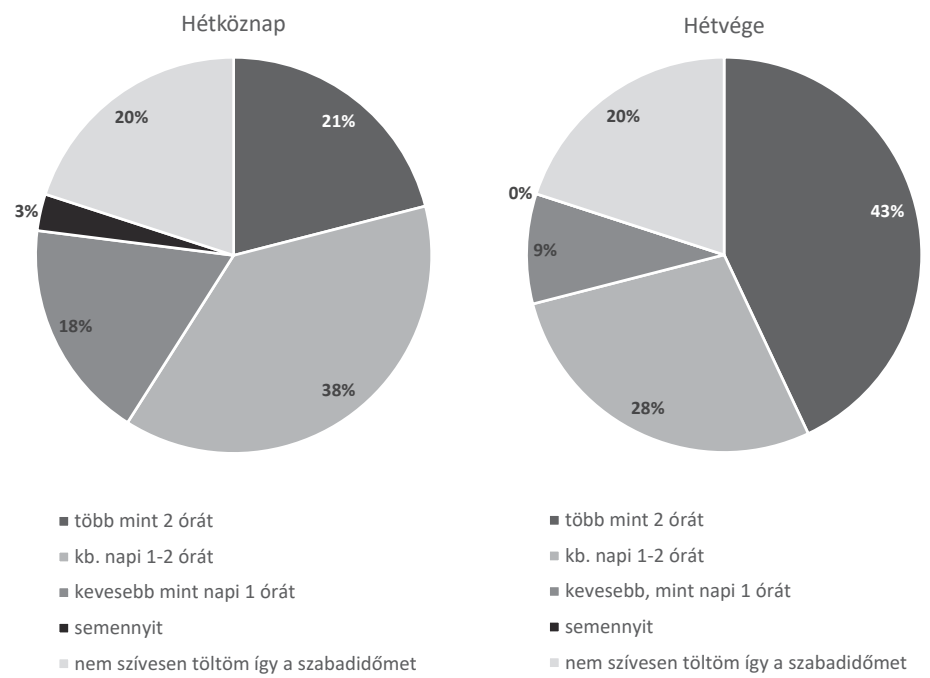

3. ábra. Televíziónézéssel töltött idő

\section{1b. Egészséges életmóddal kapcsolatos válaszok értékelése}

A fiatalok 70\%-a egészségesnek, ezen belül 18\% nagyon egészségesnek gondolja az életmódját, és csak nagyon kevesen (3\%) tartják inkább egészségtelennek.

56 , illetve 52\%-uk szerint a még egészségesebb életmód leginkább (még) több sporttal és (még) nagyobb kitartással lenne elérhetö. Annak ellenére ez a két legfontosabb faktor, hogy a sport már most is az egyik legelterjedtebb szabadidős tevékenység, és egyértelműen a legélvezetesebb is (vö. „kitartás”). Ezek mellett a több szabadidő és a jobb anyagi helyzet lenne igazán hatékony támogatás (4. ábra).

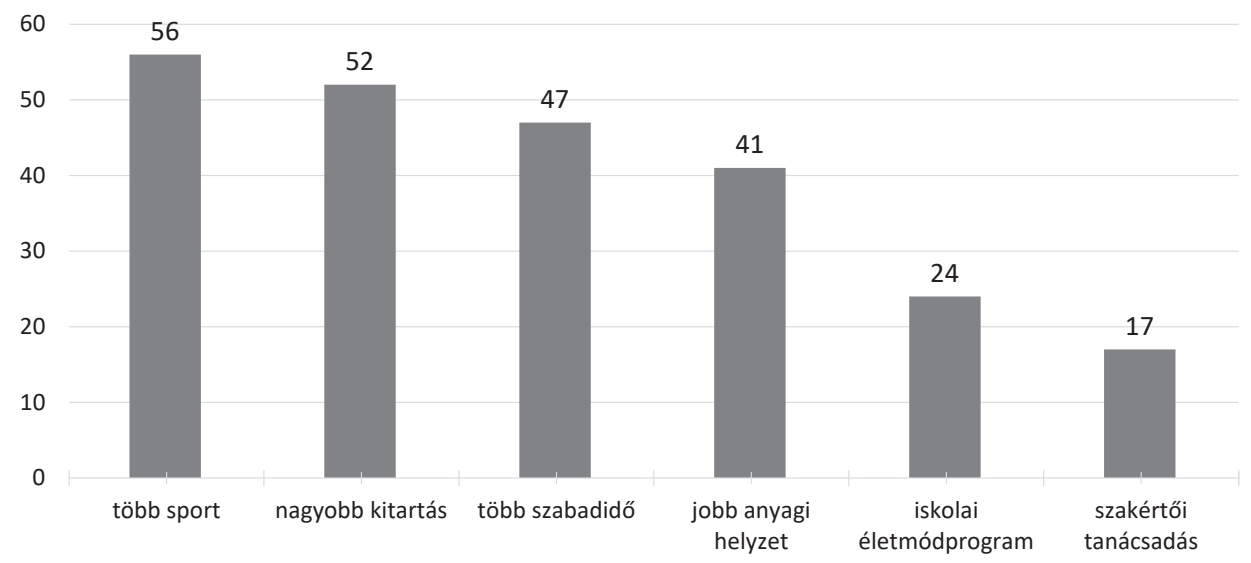

4. ábra. Az egészségesebb életmód támogatása 


\section{1c. Táplálkozási ismeretek}

A megkérdezettek kétharmada inkább tájékozottnak, egyharmaduk inkább tájékozatlannak érzi magát az egészséges étrend terén. Minden negyedik fiatal gondolja az étrendjét egészségesebbnek társaiénál (föként a budapestiek), és csak 4\% gondolja úgy, hogy egészségtelenebbül étkezik.

A fiatalok egyértelmúen az íz alapján választanának ételt - ez a domináns szempont minden szegmensben és korosztályban -, minden egyéb, beleértve az egészségességet is, csak másodlagos szempont.

Szinte kivétel nélkül naponta esznek meleg ételt, minden második megkérdezett naponta többször is. A nap „legbiztosabb” étkezése a vacsora, amit szinte mindenki heti többször fogyaszt, 92\% mindennap. A gyerekek közel fele nem reggelizik mindennap: $6 \%$ soha, $22 \%$ pedig legfeljebb heti néhányszor. $2 \%$ soha nem ebédel, további 10\%-nál pedig hetente legalább egy-két nap kimarad. Minden negyedik gyerek arról számolt be, hogy egyáltalán nem eszik édességet/rágcsálnivalót hétköznaponként, minden második pedig csak napi egyszer; a hétvégén azonban ezek fogyasztása valamivel gyakoribb.

Kétharmaduk osztja, hogy nincs egészségtelen élelmiszer, csak egészségtelen étrend. A szervezet számára szerintük szükséges tápanyaglistát a vitaminok, ásványi anyagok vezetik; sóra csak $57 \%$, cukorra csak $45 \%$ szerint van szüksége a szervezetnek.

Már szinte mindannyian hallották a kalória kifejezést, de csak egyharmaduk véli pontosan tudni azt, hogy mit jelent. $6 \%$ állítja, hogy figyel is a kalóriabevitelre, de még nekik is csak a töredékük van tisztában azzal, hogy mekkora a valós napi energiaszükséglet.

\section{1d. Élelmiszerek, címkék}

A fiatalok több mint fele legalább alkalmanként megnézi a termékek címkéjét, minden negyedik gyerek gyakran vagy mindig (5. ábra).

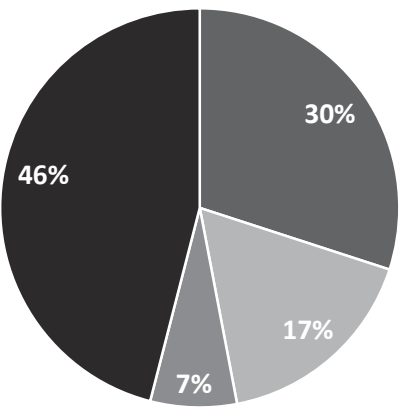

- ritkán, néha gyakran mindig asoha

5. ábra. Termékcímke-olvasás - gyakoriság 
Legtöbben a lejárati időt ellenőrzik (ötből ketten), de minden harmadik az öszszetevőket/allergén anyagokat is elolvassa. Az egyéb információk csak a rendszeres címkeolvasókat érdeklik, ideértve a nyereményjátékok leírását is. A címkéket nem rendszeresen nézők leginkább új termék vásárlásánál, ritkábban csomagolásváltáskor olvassák el az információkat; a nyereményjátékok nem igazán indukálnak nagyobb arányú olvasást.

\section{1e. Testtömeg, fogyókúra}

A vizsgálatban részt vevők 59\%-a elégedett a testtömegével: nagyjából minden negyedik fiatal szeretne soványabb lenni, minden hetedik viszont nagyobb testsúlyra törekszik.

A fiatalok 10\%-a túl van már legalább egy fogyókúrán: ők átlagosan kb. négyszer futottak neki a kilók leadásának, 2\% pedig folyamatos fogyókúrában van. Az elsődlegesen internetes tanácsok követése sokakat érint, és veszélyes megoldásokat szül!

\section{Háromnapos táplálkozási vizsgálat eredménye}

2. táblázat. A korcsoport megoszlása

\begin{tabular}{|l|c|c|}
\hline & n & \% \\
\hline $11-12$ évesek & 179 & 27,9 \\
$13-14$ évesek & 165 & 25,7 \\
$15-16$ évesek & 157 & 24,4 \\
$17-18$ évesek & 141 & 22,0 \\
összesen & 642 & 100,0 \\
\hline
\end{tabular}

A vizsgált személyek 48\%-a férfi, 52\%-a nő volt.

A vizsgált személyek antropometriai adatai: a fiatalok BMI-kategóriák szerinti megoszlása: 7,3\% sovány, 69,2\% normál, 18,4\% túlsúlyos, 5,1\% elhízott volt.

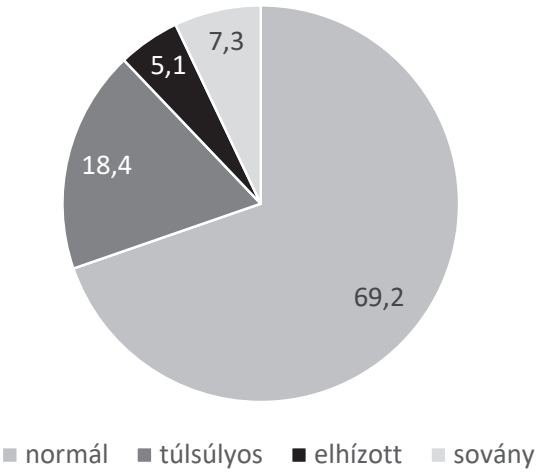

6. ábra. BMI-kategóriák szerinti megoszlás (\%) 
A sovány kategória legnagyobb arányban (19,4\%) a 17-18 éves lányok esetében, míg a túlsúly+elhízás együttese (29,7\%) a 11-12 éves fiúknál fordult elő (6. ábra).

\section{Energia- és makrotápanyagok bevitele}

\section{Energia}

A napi energiabevitel átlaga a 11-14 évesek és mindkét nem esetében megfelelt az ajánlásnak (2703 és $2392 \mathrm{kcal}), 11-12$ évesek esetén kevéssel az ajánlás alatt, azonban a 13-14 éves fiúk esetén az ajánlás feletti bevitel volt. Az energiabevitel határértékei a teljes minta esetén 88 százalék, az egyes korcsoportokat figyelembe véve az esetek 81-92 százalékában a normál beviteli tartományban (az ajánlás $70-130 \%$-án belül) volt. Többletenergia bevitele legmagasabb arányban (21,8\%) a 17-18 éves fiúk esetén volt megfigyelhető (7. ábra).

$\begin{array}{lllll} & 11-12 \text { év } & 13-14 \text { év } & 15-16 \text { év } & 17-18 \text { év } \\ \text { Fiú } & 2609 & 2858 & 3020 & 3116 \\ \text { Lány } & 2268 & 2360 & 2247 & 2370\end{array}$

7. ábra. 11-18 évesek korcsoportonkénti napi energiabevitele (kcal/nap)

\section{Makrotápanyagok}

Az energiát adó tápanyagok megoszlása: az összes energián belül a zsír energia\% (en\%) minden korcsoportban, mindkét nem esetén kb. 5-6\%-kal az ajánlott maximum (30 en\%) felett volt. A kritikus határérték felett (magasabb, mint az ajánlott bevitel 130\%-a) zsírt fogyasztók aránya átlagosan több mint 40\% volt. Az n-3 és n-6 zsírsavak aránya átlagosan 1:27 körül van (az ajánlott 1:5 helyett), ez az arány már ugyanolyan kedvezőtlen, mint a felnőttekre jellemző átlag, az elmúlt évek vizsgálati eredményeihez képest romlott.

A szénhidrátból származó energia átlaga jóval alatta van (49\%) az ajánlott 57 en\%-nak, de ezen belül a hozzáadott cukorból származó energia meghaladja (11,7 en\%) az ajánlott 8 max. 10 en\%-ot - ami rendkívül kedvezőtlen -, legmagasabb a 13-14 éves fiúk és a 17-18 éves lányok esetében.

A fehérjebevitel átlaga minden csoportban magasabb (14-15 en\%) az ajánlottnál (az elmúlt huszonöt évben gyakorlatilag minden vizsgálatban hasonló), és mintegy $28 \%$ a határérték felett fogyasztók aránya. A testtömegre számított fehérjebevitel átlaga minden korcsoportban jóval az ajánlott $(1,0-1,2 \mathrm{~g} / \mathrm{ttkg})$ felett van, legmagasabb $(2,15 \mathrm{~g} / \mathrm{ttkg})$ a 11-12 éves fiúk esetében.

Minden korcsoport esetében a koleszterin napi beviteli átlaga (370 mg) jóval az ajánlott (250 és $300 \mathrm{mg} / \mathrm{nap}$ ) felett volt. A határértékeket is figyelembe véve minden korcsoportban a fiatalok 40-50\%-a magasabb koleszterinbevitelt mutatott, 
mint az ajánlott maximális érték. Az élelmi rost átlagos bevitele (23-26 g/nap) közel megfelelö, azonban a fiatalok kb. egyharmada esetében határérték alattinak számít (8. ábra).

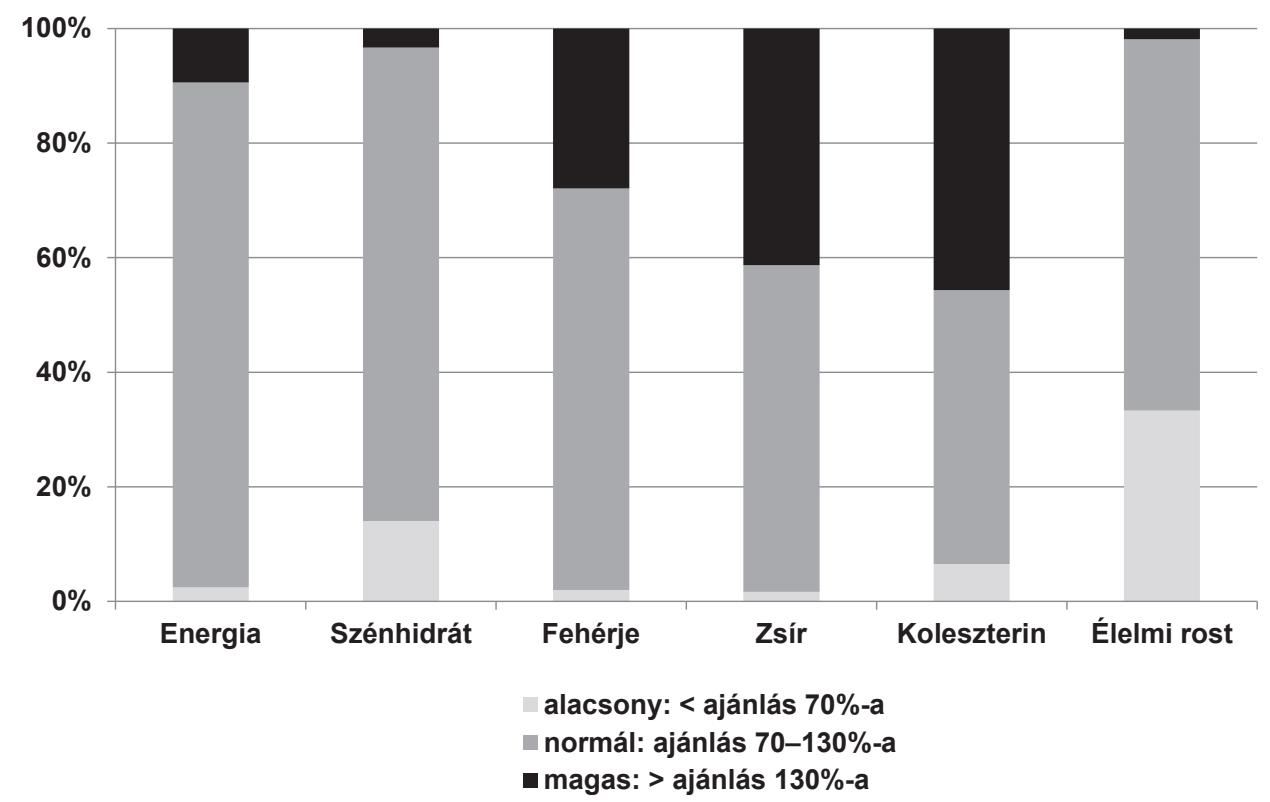

8. ábra. 11-18 évesek energia- és makrotápanyag-bevitele az ajánláshoz viszonyított kategóriák szerint

\section{Ásványi anyagok bevitele}

Az általánosan említhető népegészségügyi probléma részeként jelenik meg, hogy minden vizsgált csoportban kiemelkedően magas a napi nátriumbevitel, eléri az ajánlott maximális bevitel 300-400\%-át is; gyakorlatilag minden fiatal (99,5\%) Na-bevitele meghaladja a kritikus felső határértéket (9. ábra). A kardiovaszkuláris betegségek rizikófaktorának számító nátrium/káliumhányados átlaga jelentősen magasabb $(2,0)$ az ajánlott $0,6-0,8$ aránynál.

A csontfejlődésben fontos szerepet játszó ásványi anyagok közül a kalcium átlagos napi bevitele korcsoportonként változó mértékben kissé elmarad az ajánlott 1000 mg értéktől - a 15-18 éves fiúk esetében eléri azt. Összességében a fiatalok közel 35\%-a naponta kevesebb kalciumot fogyaszt, mint a szükségleti ajánlás 70\%-a. Ezzel párhuzamosan a napi foszforbevitel átlaga (1159 mg) meghaladja az ajánlott $775 \mathrm{mg}$ értéket, így kedvezőtlen a kalcium és foszfor hányadosa is.

A magnézium napi bevitele kielégítő, nem mutat jelentős hiányt egyik korcsoport esetében sem. 
A cink átlagos bevitele kevéssel alatta van az ajánlott napi 9-10 mg értéknek, az alacsony bevitel a fiatalok mintegy $20 \%$-át érinti.

Az átlagos vasbevitel a 11-14 éves korcsoport esetén eléri az ajánlott értéket (fiú 10, lány $12 \mathrm{mg}$ ), azonban 15-18 éves korban a nagyobb ajánlott bevitel (fiú 11, lány $15 \mathrm{mg}$ ) lányok esetén nem teljesül, 57-65\%-uk kritikusan alacsony vasbevitelt mutat. Az eredmények nem tartalmazzák az étrend-kiegészítőkből származó bevitelt (9. ábra).

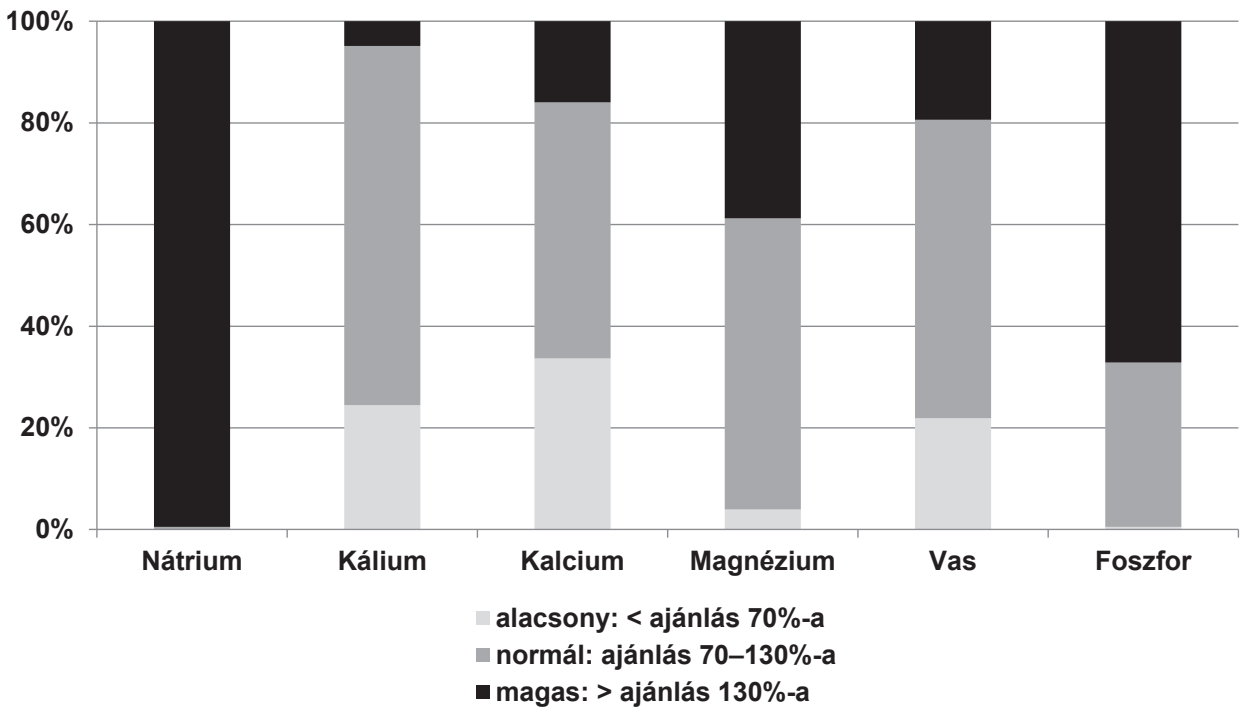

9. ábra. 11-18 évesek ásványianyag-bevitele az ajánláshoz viszonyított kategóriák szerint

\section{Vitaminok bevitele}

A vitaminok közül a zsíroldékony A-vitamin bevitelére jellemző retinol-ekvivalens napi átlagos bevitele mérsékelten alacsonynak mondható $(0,6-0,8 \mathrm{mg})$, így a 11-14 évesek esetén mintegy 55\%, a 15-18 évesek közt mintegy $45-65 \%$ a jelentős beviteli hiány aránya (10. ábra).

A D-vitamin napi beviteli ajánlását kizárólag táplálkozással nem könnyü teljesíteni, ehhez időközönként kiemelkedően magas kalciferol-tartalmú élelmiszereket kell fogyasztani (az aktív formák szervezetben való képződése érdekében pedig növelni kell a szabad levegôn töltött órák számát). A vizsgált csoportok gyakorlatilag 98\%-a esetén határérték alatti D-vitamin-bevitel volt megfigyelhetö.

A tokoferol (E-vitamin) beviteli átlaga megfelelőnek mondható (15-19 mg), potenciális hiány csak a fiatalok 7-8\%-ában volt kimutatható. 
A B-vitamin-csoport tagjaiból az ellátottság általában jó, hiánnyal csak a $B_{12}$ esetében kell 15-20\% arányban számolni, a csoport többi tagja esetén ez az arány $10 \%$ körüli.

C-vitamin esetén az átlagos bevitel megfelelönek mondható (79 mg), azonban korcsoportonként és nemenként a 11-14 évesek fiatalok 12-16\%-a, míg 15-18 éves korban 33-40\%-a esetében így is hiányos a napi bevitel - elsősorban a zöldség- és gyümölcsfélék fogyasztásának jelentős különbségei miatt.

A folsav a fiatalok mintegy 40-45\%-a esetében hiányos bevitelt mutat, átlaga 130 és $170 \mu \mathrm{g} /$ nap közti (az ajánlott érték 180 és $200 \mu \mathrm{g}$ ). Az eredmények nem tartalmazzák az étrend-kiegészítőkből származó bevitelt (10. ábra).

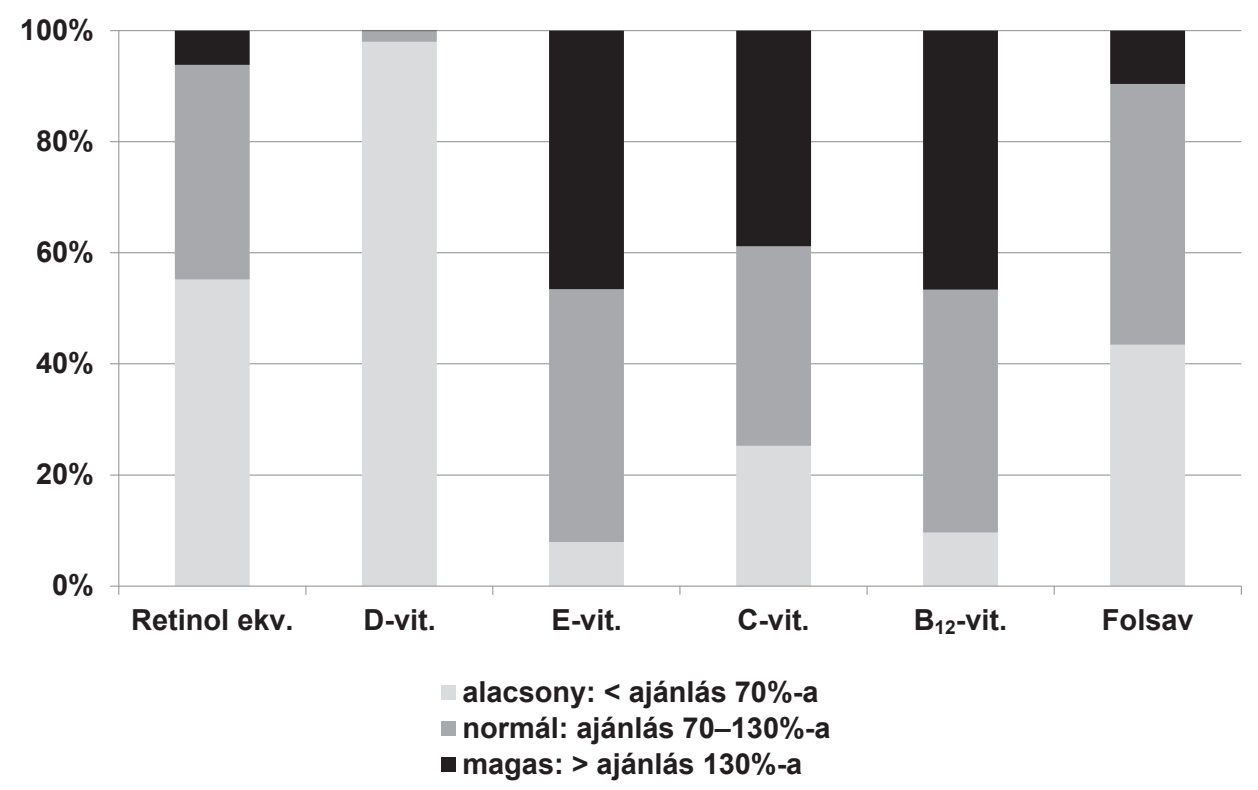

10. ábra. 11-18 évesek vitaminbevitele az ajánláshoz viszonyított kategóriák szerint

\section{Élelmiszer-fogyasztás}

- Zöldség-, főzelékfélékből - burgonyával együtt - a 11-18 éves fiatalok naponta átlagosan 277 (247-303) g-ot fogyasztottak.

- Gyümölcsfélékböl - magas gyümölcshányadú gyümölcslevekkel együtt - a 11-18 évesek naponta átlagosan 182 (170-230) g-ot fogyasztottak.

- A zöldség- (169 g) és gyümölcsfélék (100 g) burgonya- és gyümölcslé fogyasztása nélküli együttes mennyisége azonban csak mintegy $270 \mathrm{~g} / \mathrm{nap} /$ fö, ami jóval alatta van az adott korcsoportú fiatalok számára ajánlott (kb. 400-450 g) mennyiségnek. 
- A 11-18 évesek tej- és tejtermék fogyasztása összességében 309 g/nap, legmagasabb a 17-18 éves fiúk esetében (346 g), legalacsonyabb a 13-14 éves lányoknál (256 g/nap) volt, ami jelentősen elmarad a kívánatos mintegy $500 \mathrm{~g} /$ nap mennyiségtöl (11. ábra).

\begin{tabular}{|c|c|}
\cline { 2 - 2 } \multicolumn{1}{c|}{} & g/fö/nap \\
\hline Gabonafélék & 263 \\
\hline nem teljes értékü + fehér kenyér & 237 \\
\hline teljes értékü + barna kenyér & 26 \\
\hline Zöldségfélék együtt & 277 \\
\hline zöldség- és fözelékfélék & 169 \\
\hline burgonya & 108 \\
\hline Gyümölcsfélék együtt & 182 \\
\hline gyümölcsök & 100 \\
\hline gyümölcslé & 82 \\
\hline Tej és tejtermékek & 309 \\
\hline
\end{tabular}

11. ábra. Különböző élelmiszercsoportok fogyasztása

- Teljes értékủ gabonákat + barna kenyérféléket összességében a 11-18 évesek mintegy 26 g mennyiségben, míg nem teljes értékü gabonákat + fehér kenyérféléket $237 \mathrm{~g} /$ nap mennyiségben fogyasztottak - a felnőttekben is meglévő, jellemző különbséggel.

- A teljes értékủ gabonákon belül a teljes értékü gabonapelyhek, müzlifélék fogyasztása csak mintegy $6,2 \mathrm{~g} / \mathrm{nap}$.

- A diófélék, olajos magvak készítményei, például mogyorókrém fogyasztása már a 11-12 éves korcsoport esetén is csak 1,3 g/nap (11-18 éves átlag: 1,1 g), jelentősen kevesebb, mint a korábbi vizsgálatok kisgyermekei (0-3 és 4-10 évesek) körében.

- Míg cukorkafélék fogyasztása csak nagyon kis mennyiségben volt kimutatható az adott időszakban, csokoládéféléket a fiatalok napi átlagos $8,5 \mathrm{~g}$ mennyiségben fogyasztottak.

- Édes kekszek, nápolyik fogyasztása a korcsoport növekedésével fokozatosan csökken, 11-12 éves korban még 12 g/nap, míg 16-18 éveseknél már csak $8 \mathrm{~g}$, a 11-18 év átlagában $10 \mathrm{~g} / \mathrm{nap}$.

- A víz (csapvíz) fogyasztása átlagosan $521 \mathrm{~g} / \mathrm{nap}$, míg az ásványvízé átlagosan $295 \mathrm{~g}$ volt.

- A húsok közül a baromfifélék fogyasztása mintegy $67 \mathrm{~g}$, a sertéshúsé $43 \mathrm{~g}$, míg a marhahús fogyasztása $5 \mathrm{~g} /$ nap volt. 
- A felvágottak közül sajnos nem a sovány sonkafélék fogyasztása (10-12 g/ nap körül), hanem a közepesen zsíros felvágottak fogyasztása volt a legmagasabb (átlagban $32 \mathrm{~g} / \mathrm{nap}$, legmagasabb a 15-16 éves fiúknál, $48 \mathrm{~g}$ ), a kolbász- és szalámifélék fogyasztása $6 \mathrm{~g}$ /nap körüli érték.

\section{Víz- és folyadékbevitel}

Az ételekből és italokból származó víz (mint tápanyag; total water, TW) bevitele, valamint a különféle folyadékok fogyasztása is korral növekvő mennyiséget mutatott. A víz (TW) 11-12 évesek esetén 1919 g/nap, 17-18 éveseknél 2302 g/nap, míg a folyadékfogyasztás 1439 és $2025 \mathrm{~g} /$ nap ezen korcsoportokban. A testtömegre számított víz- és folyadékbevitel azonban a testméret növekedése (és feltételezhetően a folyadékfogyasztási szokások változása) miatt a korral csökken. Az egy testtömeg kg-ra vonatkoztatott víz 11-12 évesek esetén 42,4 g/nap, 17-18 éveseknél már csak 35,2 g/nap, míg a folyadékfogyasztás 31,2-ről 27,6 g/nap mennyiségre csökken ezen korcsoportokban.

\section{Testtömeg-kategóriák és tápanyagok bevitele}

Vizsgáltuk a fiatalok testtömegindex alapján meghatározott „tápláltság jelző” kategóriák (BMI-kategóriák: sovány, normál, túlsúlyos és elhízott), valamint a fontosabb energia- és makrotápanyagok bevitelének összefüggését. Az összesített adatok esetén különbség mutatkozik az egyes BMI-kategóriák közt a napi energia-, valamint a makrotápanyag-bevitelben, azonban az egyes kor- és nemek szerinti csoportok esetében a tendenciák nem mindenütt érvényesülnek. A minden korcsoportot tartalmazó BMI-kategóriák sorrendjében: sovány 2464, normál 2594, túlsúlyos 2660 és elhízott $2970 \mathrm{kcal} / \mathrm{nap}$ - egyértelmü trendnek tünik, amelyet felnőtt populáció esetében csak ritkán lehet megfigyelni. A két szélső (sovány és elhízott) kategória között kb. 20\% energiatöbblet-bevitel mutatható ki. Az egyes makrotápanyagok esetében (fehérje, zsír és szénhidrát) - változó mértékben - szintén megfigyelhető ez a tendencia.

\section{Korcsoport és nem szerint}

Az egyes kor- és nem-csoportok esetében a testtömegindex függvényében növekvő energia- és makrotápanyag tendencia nem mindenütt érvényesül.

A makrotápanyagok közötti energiamegoszlás azonban nem mutat ilyen szerkezeti különbségeket, gyakorlatilag az energia\%-ok vonatkozásában nincs különbség az egyes BMI-csoportok között. A vizsgált csoportot tekintve, az elhízás táplálkozási okaként tehát nem a különböző makrotápanyagok aránya, hanem elsősorban a többletenergia-bevitel tehető felelőssé (az egyéb életmódi faktorok - fizikai aktivitás, mentális egészség stb. - mellett).

Korrelációs vizsgálattal is kimutatható a BMI és az energia, valamint a makrotápanyagok gramm/fö érték szoros pozitív összefüggése. Ez az összefüggés a 
testtömeg, illetve a testmagasság esetén magyarázható lenne a kor növekedése miatti természetes méretnövekedéssel, azonban a BMI esetében már nem. De nem feledkezhetünk meg arról, hogy 18 éves korig a kor növekedésével élettanilag is változik a BMI (lassan növekvő/változó határértékekkel) - ezért ez a jelenség mélyebb elemzést és értékelést igényelhet. A BMI viszont nem mutat összefüggést a makrotápanyagok energia\% értékével. Felnőttek esetében (csoportszinten) ritkán látni szoros összefüggést a bevitt energia mennyisége és a testtömegindex között, mivel az esetek többségében akkor már beállt (steady state) állapotú testtömeg-anyagcsere rendszert látunk, melyben a megnövekedett testtömeg fenntartása alacsonyabb energiabevitel mellett is lehetséges.

\section{ÖSSZEFOGLALÁS}

Összefoglalóan elmondható, hogy a vizsgált 11-18 éves korcsoportú fiatalok táplálkozásában a felnőtt lakosságra is jellemző hibák nyomai már felfedezhetők. $\mathrm{Az}$ átlagban megfelelőnek mondható napi energiabevitel több mint harmada zsiradékból származik, amely a táplálkozási szokások helytelen rögzülése esetén tovább növekszik a későbbi életkorokban. Ezzel párhuzamosan a zsírsavösszetétel is kifejezetten kedvezötlen szerkezetet mutat. Az arányaiban alacsony szénhidrátbevitelen belül magas a finomított cukrok aránya. Az élelmi rost fogyasztásának átlaga minden korcsoportban az ajánlás közelében vagy kissé alatta volt, a koleszterin viszont jelentős beviteli többletet mutat. A nátrium/káliumhányados átlaga a kívánatosnál jelentősen magasabb, ezen faktorok együttes jelenléte pedig növeli a felnőttkorban kialakuló szénhidrát-anyagcsere-, illetve szív-érrendszeri típusú megbetegedések kialakulásának kockázatát.

A csontfejlődés szempontjából kiemelkedően fontos kalcium bevitele a 11-18 éves fiatalok mintegy $35 \%$-a esetén kifejezetten alacsony, amit tovább ront a foszfor magas beviteli szintje.

A vas bevitele a fiúk esetében megközelíti az ajánlott mennyiséget, a lányok esetében azonban jelentős arányú vasbeviteli hiánnyal kell számolni.

A D-vitamin-ellátottság gyakorlatilag elégtelen minden vizsgált korcsoport esetében. Az egyéb vitaminok közül nagyobb mértékben csak a folsav bevitelének hiányával kell számolni - ez viszont mindenképpen fontos népegészségügyi feladat volna.

Az egyes élelmiszercsoportok fogyasztásában már karakteresen felfedezhetőek a felnőttekre jellemző táplálkozási szokások, például a finomított fehér lisztből készült kenyerek, pékáruk fogyasztásának jelentősen nagyobb aránya a teljes értékủ gabonafélékhez képest. A zöldség- és főzelékfélék, illetve gyümölcsök mellett a tejtermékek fogyasztása is alacsonyabb, mint azt az ajánlások és a tápanyagcélok indokolnák. A sovány felvágottak fogyasztása elmarad 
a félzsírosaké mellett, és megjelenik az üdítőitalok, kekszek és chipsek fogyasztása is.

Az egyén felelősségének szerepe, az egészséges életmód fontossága a lakosság, így a fiatalok körében egyre inkább bekerül a köztudatba. Az egészséges életmóddal kapcsolatos ismeretek és az egyéni felelősség belátása viszont nem jelenti feltétlenül a gyakorlati megvalósítást.

Ahhoz, hogy a fiatalok képesek legyenek változtatni az életmódjukon, számos dologra van szükség (ismeretekre, motivációra, támogatásra, a változásra alkalmassá tevő élethelyzetre, jó szakemberekre stb.), de leginkább arra, hogy ők maguk aktív alakítóivá, bevont szereplőivé, végrehajtóivá váljanak egy jól megkonstruált életmódváltó programnak.

\section{IRODALOM}

Ahrens, W. et al. (2014): Prevalence of Overweight and Obesity in European Children Below the Age of 10. International Journal of Obesity, 38. Suppl. 2. S99-107. DOI: 10.1038/ijo.2014.140, https://www.nature.com/articles/ijo2014140

CDC - Centers for Disease Control and Prevention (1997): Guidelines for School Health Programs to Promote Lifelong Healthy Eating. Journal of School Health, 67, 1, 9-26.

Erdei G. et al. (2018): Substantial Variation across Geographic Regions in the Obesity Prevalence among 6-8 Years Old Hungarian Children (COSI Hungary 2016). BMC Public Health, 18, 611. DOI: 10.1186/s12889-018-5530-6, https://bmcpublichealth.biomedcentral.com/articles/10.1186/ s12889-018-5530-6

EUFIC (2012): Lower Socio-economic Status and an Unhealthy Diet: What Is Their Relationship? 26 September 2012. https://www.eufic.org/en/healthy-living/article/lower-socio-economic-status-and-an-unhealthy-diet-underlying-food-selection

Kis T. (2016): Kutatás az internetes egészségügyi információszerzésröl. Budapest: Szinapszis Kft. https://www.szinapszis.hu/hu/hirek/kutatas-az-internetes-egeszsegugyi-informacioszerzesrol

Konttinen, H. et al. (2013): Socio-economic Disparities in the Consumption of Vegetables, Fruit and Energy-dense Foods: The Role of Motive Priorities. Public Health Nutrition, 16, 5, 873882. DOI: $10.1017 /$ S1368980012003540, https://bit.ly/2TjFXRv

Lobstein, T. - Jackson-Leach, R. - Moodie, M. L. et al. (2015): Child and Adolescent Obesity: Part of a Bigger Picture. The Lancet, https://doi.org/10.1016/S0140-6736(14)61746-3

NEFI (2015): Egészségkommunikációs felmérés. Budapest: NEFI, http://www.egeszseg.hu/szakmai_oldalak/oldal/szakmai-anyagok/szakmai-anyagok-egeszsegkommunikacios-felmeres/

Németh Á. - Költő A. (szerk.) (2014): Egészség és egészségmagatartás iskoláskorban. Budapest: NEFI, http://www.egeszseg.hu/szakmai_oldalak/assets/cikkek/16-05/egeszseg-es-egeszsgegmagatartas-iskolaskorban-2014.pdf

Nikoloudakis, I. A. et al. (2016): Examining the Correlates of Online Health Information-seeking Behavior among Men Compared with Women. American Journal of Men's Health, 12, May, DOI: 10.1177/1557988316650625, https://journals.sagepub.com/doi/full/10.1177/1557988316650 625? url ver $=$ Z39.88-2003\&rfr id $=$ ori:rid:crossref.org\&rfr_dat $=$ cr pub\%3dpubmed

Pedersen, T. P. - Meilstrup, C. - Holstein, B. E. et al. (2012): Fruit and Vegetable Intake Is Associated with Frequency of Breakfast, Lunch and Evening Meal: Cross-sectional Study of 11-, 13-, 
and 15-year-olds. International Journal of Behavioural Nutrition and Physical Activity, 9, 9. DOI: 10.1186/1479-5868-9-9, https://ijbnpa.biomedcentral.com/articles/10.1186/1479-5868-9-9

Story, M. - Neumark-Sztainer, D. - French, S. A. (2002): Individual and Environmental Influences on Adolescent Eating Behaviors. Journal of the American Dietetics Association, 102, 3, s40s51. DOI: 10.1016/S0002-8223(02)90421-9

WHO (2014): WHO European Food and Nutrition Action Plan 2015-2020. Geneva: WHO, http:// www.euro.who.int/_data/assets/pdf_file/0008/253727/64wd14e_FoodNutAP_140426.pdf

WHO (2016): WHO Report of the Commission on Ending Childhood Obesity. Geneva: WHO, http://www.aho.afro.who.int/networks/sites/default/files/final_report_of_the_commission_ on_ending_childhood_obesity_0.pdf

WHO (2017): WHO Recommendations on Adolescent Health. Geneva: WHO, https://www.who. int/maternal_child_adolescent/documents/adolescent-health-recommendations/en/ 